\title{
Greek energy and protein feeding standards for growing and fattening cattle
}

\section{A. GIOUSELJANNIS}

Livestock Institute, Paralimni, Giannitsa, Greece.

This paper will be restricted to a brief description of the energy system used for ruminants in Greece at the present time. This is the Starch Equivalent system devised by Kellner. This system of net energy was introduced in our country a long time ago and has been adapted by the two Schools of Agriculture at the Universities of Thessaloniki and Athens, as well as by the Ministry of Agriculture.

As is well know, in trying to estimate the net energy of a feed, Kellner assumed that when feed in excess of the maintenance level is consumed by the mature animal it is deposited as fat. In this way, by adding the feed under investigation to the basal ration (which covered all the maintenance requirements of the animal) he was able to measure the net energy value of the feed with adequate accuracy.

Initially, Kellner used as a measuring unit the calorie but he avoided using it in practice since it was not easily understandable by the farmers. In the same way, he avoided the use of the unit of fat deposition because he did not want to create the impression that the system concerned only fattening animals.

At the present time in Greece we use the revised SE unit described in the DLG Tables (1968) for ruminants which are widely used by the agricultural scientists. In these Tables the nutrient requirements for each category of animals are also given. Table 1 shows the nutrient requirements for fattening beef cattle.

\begin{tabular}{|c|c|c|c|c|c|}
\hline & $L W \quad(k g)$ & DM (kg) & $\operatorname{DCP}(g)$ & $S E \quad(q)$ & $\mathrm{CP}: \mathrm{SE}$ \\
\hline \multicolumn{6}{|l|}{$\begin{array}{l}\text { Beef cattle up } \\
\text { to } 13 \text { months old }\end{array}$} \\
\hline $\begin{array}{l}5-8 \text { months } \\
9-13 \text { months }\end{array}$ & $\begin{array}{l}125-250 \\
250-400\end{array}$ & $\begin{array}{l}4-6 \\
8-10\end{array}$ & $\begin{array}{l}500-600 \\
750-850\end{array}$ & $\begin{array}{l}2400-3000 \\
3900-4800\end{array}$ & $\begin{array}{l}5.0 \\
5.4\end{array}$ \\
\hline \multicolumn{6}{|l|}{$\begin{array}{l}\text { Beef cattle up } \\
\text { to } 18 \text { months old }\end{array}$} \\
\hline $\begin{array}{l}5-12 \text { months } \\
13-18 \text { months } \\
19-24 \text { months }\end{array}$ & $\begin{array}{l}125-280 \\
280-500 \\
400-600\end{array}$ & $\begin{array}{c}3-8 \\
9-13 \\
12-15\end{array}$ & $\begin{array}{c}450 \\
900-950 \\
900-950\end{array}$ & $\begin{array}{l}1900-2600 \\
5000-6000 \\
5500-6500\end{array}$ & $\begin{array}{l}5.0 \\
6.0 \\
6.5\end{array}$ \\
\hline
\end{tabular}
feed.

The nutritional value of a feed is estimated initially by a proximate analysis of the

Then the net energy is calculated, usually by using :

a) the digestibility coefficients which are included in the DLG Tables for each separate feed ;

b) the factors which should be taken into account for each nutrient ;

c) the value number for cereals or the correction factor for roughages. 
Only in somes cases is the nutritional value of a feed determined by digestibility trials with experimental animals.

It has now been proved that Kellner's Starch Equivalent system is not accurate. However, although most of its weaknesses are now apparent, it is still considered the best method of estimating the nutritional value of feeds in Greece since the new systems (RosTOCK, VAN Es, ARC) are not yet widely known.

\title{
Irish Republic energy and protein feeding standards for growing and fattening cattle
}

\author{
T.W. GRIFFITHS \\ The Agricultural Institute, Dunsinea, Castleknock, \\ Co. Dublin, Ireland.
}

\section{Introduction}

There are no officially adopted feeding standards in the Irish Republic but both the Scandinavian Feed Unit and the British Starch Equivalent system have been used. However, when the new system of energy feeding standards (MAFF, 1975) based on metabolisable energy (ME) was adopted in Britain it was not officially adopted in Ireland although the system is being used on a limited scale. A joint committee representing agricultural and veterinary research and education has recommended a system of energy feeding standards similar to, but not identical with, that used in the UK. The proposed system is described in this paper.

\section{A. Energy feeding standards for growth}

The system is based on the expression of both the nutritive value of feeds and the nutritive requirements of animals in terms of $\mathrm{ME}$, and uses the megajoule (MJ) as the basic unit of energy. Requirements for ME are obtained from the calculated net energy (NE) requirement for maintenance and growth and the partial efficiency $(k)$ with which dietary $\mathrm{ME}$ is used to satisfy these requirements.

\section{Energy requirements for maintenance}

Minimum requirement for maintenance - fasting metabolism (FM) is considered to be the $\mathrm{NE}$ requirement for maintenance and is related to liveweight (W). Efficiency of utilisation of ME for maintenance $\left(k_{m}\right)$ is related to the metabolisability of the diet $(\mathrm{Q})$ :

$$
k_{m}=0.287 \mathrm{Q}+0.55
$$

However, for the range of $\mathrm{Q}$ values which are normally found in Ireland $k_{m}$ lies between 0.68 and 0.76 and a mean value of 0.72 has been taken. The value for $F M$ of $360 \mathrm{~kJ} \mathrm{ME} / \mathrm{kg} \mathrm{W}^{0.75}$ has been adopted. An additional allowance for activity (A), mainly locomotion, of 5 per cent has also been included. Metabolisable energy requirements for maintenance $\left(\mathrm{ME}_{m}\right)$ are therefore given by:

$$
\mathrm{ME}_{m}=\frac{\mathrm{FM}}{0.72}+\mathrm{A}=525 \mathrm{~kJ} / \mathrm{kg} \mathrm{W^{0.75 }}
$$

(Estimates of maintenance requirements made by regression analysis of ME intake on energy and nitrogen retention in housed Friesian cattle have given values of around $480 \mathrm{~kJ} \mathrm{ME} / \mathrm{kg} \mathrm{W}^{0.75}$ ). 